\title{
FAIRNESS OF STRATEGIC RESOURCE ALLOCATION, TEAM COMMITMENT AND COMMITMENT TO IMPLEMENTING STRATEGY IN INDONESIAN INTERNATIONAL JOINT VENTURES
}

\author{
Syukri Lukman \\ Faculty of Economics, Universitas Andalas, Indonesia \\ e-mail: cuwy52@gmail.com \\ Aizzat Mohd. Nasurdin \\ School of Management, Universiti Sains Malaysia, Malaysia \\ e-mail: aizzat@usm.my \\ Osman Mohamad \\ Graduate School of Business, Universiti Sains Malaysia, Malaysia \\ e-mail: Osman@usm.my
}

\begin{abstract}
This study seeks to investigate the relationship between fairness of strategic resources allocation, management team's commitment to multiple parties, and strategy of international joint ventures (IJVs) in Indonesia. Using a sample of $113 \mathrm{IJVs}$, the results of the regression analyses showed a positive relationship between fairness of strategic resources allocation and team's commitment to implementing strategy whereby team commitment served as a mediator. In addition, fairness of strategic resources allocation was positively related to team commitment and team's strategy. Implications, limitations, and suggestions for future research are discussed.
\end{abstract}

Keywords: Fairness of Strategic Resources Allocation, Team Commitment, Commitment to Implementing Strategy, International Joint Ventures, Indonesia

\begin{abstract}
Abstak
Penelitian ini bertujuan untuk mengkaji hubungan antara keadilan alokasi sumber daya strategis, komitmen manajemen tim ke beberapa pihak, dan strategi perusahaan patungan internasional di Indonesia. Penelitian ini menggunakan sampel sebanyak 113 perusahaan patungan internasional. Hasil analisis regresi menunjukkan adanya hubungan positif antara keadilan alokasi sumber daya strategis dan komitmen tim untuk menerapkan strategi dimana komitmen tim bertindak sebagai mediator. Selain itu, keadilan alokasi sumber daya strategis mempunyai hubungan positif dengan komitmen tim dan strategi tim.
\end{abstract}

Kata kunci: Keadilan Alokasi Sumber Daya Strategis, Komitmen Tim, Komitmen Implementasi Strategi, Perusahaan Patungan Internasional, Indonesia

\section{INTRODUCTION}

Inter-firm collaboration has become an increasingly common phenomenon in the pursuit for international competitive advantage. Among the reasons cited for alliance formation include the need to achieve economies of scale, reduce risk, lower transaction costs, exchange complementary resources, and engage in mutual learning (Beamish, 1988; Buchel, et al., 1998; Hamel, 1991; Harrigan, 1986; Kogut, 1988). As noted by Tiessen and Linton (2000), even though forming alliances is considered good in principle, it can be risky in practice. International joint-venture (hereafter termed as IJV) is one of the most popular form of international cooperative arrangements. Foreign firms often use IJVs as a means of entering new markets 
(Harrigan, 1986). Joint-venture operates like stand-alone firm and has to engage in all different types of regular business activities and engage in external relationships similar to that of any independent firm. However, an IJV is more complex than a single organization since it involves multiple "internal" inter-organizational linkages (Yan and Luo, 2001). An IJV is a legal entity created by two or more organizations (known as the "parents"), at least one of which is headquartered in another country (Johnson, et al., 2002). In managing an IJV, one major challenge for managers would be managing their "dual commitment" because an IJV grows from two or more parent companies having shared ownership, resources, and strategic decisionmaking processes.

Most research on organization commitment has focused on individual commitment (Cohen, 2006; Mathieu and Zajac, 1990; Meyer and Allen, 1997; Mowday, et al., 1979). Few scholars (Bishop and Scott, 1996; Bishop, 2000; Ostroff, 1992), however, have examined commitment at the team level. According to Johnson et al. (2002), in the case of the IJV, even though commitment of individual team members may vary, examining its top management team's commitment is relevant since this team serves as the key player between the IJV and its parents. Besides, past studies on organizational commitment have been based overwhelmingly on both business and nonbusiness domestic organizations with little focus on international collaborations. Hence, there is a need to explore the commitment construct and its determinants from the perspective of the IJV.

Since organizational unfairness have been found to increase social conflict and obstruct cooperation in a variety of context (Fortin and Fellenz, 2008; Lind, 1995), it would be interesting to investigate the effect of this variable within the context of the IJV. Therefore, this study hopes to provide information on how fairness of strategic resource allocation (distributive fairness) can influence management team's commitment to implementing strategy with team commitment to IJV organization as a mediator. Specifically, we intend to investigate the relationship between fairness of strategic resources allocation and team's strategy, and to examine the role of team's commitment to multiple parties as mediators in the fairness of stra- tegic resources allocation (distributive fairness) -commitment to implementing strategy relationship. We analyze these issues in IJVs within the manufacturing sector of Indonesia.

\section{REVIEW OF LITERATURE \\ Organizational Commitment and Multiple Commitments}

Commitment has been extensively defined, measured, and researched. Within the field of organizational behaviour, organizational commitment has received the most attention (Bloomer and Schroder, 2003; Kuvaas, 2006; Mowday, Porter and Steers, 1982, Riketta, 2002). In many cases, these studies utilized the definition and measure developed by Porter and others (Porter et al., 1974; Mowday et al., 1982; Mowday et al., 1979). Specifically, organizational commitment is defined as "the relative strength of an individual's identification with and involvement in a particular organization" (Mowday et al., 1982). It can be characterized by at least three factors: (a) a strong belief in and acceptance of the organization's goal and values, (b) a willingness to exert considerable effort on behalf of the organization, and (c) a strong desire to maintain membership in the organization. However, it can be argued that the organizational commitment construct can only be accurately understood as a collection of multiple commitments to various groups that comprise the organization. This is because the organization may not be a monolithic, undifferentiated entity but as comprising of coalitions and constituencies, each of which have their own set of goals and values that may be in conflict with the goals and values of other organizational groups (Reichers, 1985). These studies found that individuals can exhibit commitment to more than one entity at the same time and their level of commitment to each of them differs.

In an IJV, a manager must be committed to three potential parties namely: the IJV itself, the foreign parent company, and the local parent company. The complexity of an IJV tends to be higher compared to ordinary subsidiaries of multinational enterprises (MNEs). According to the exchange theory (Blau, 1964) and commitment literature (Meyer and Allen, 1997; Mowday et al., 1979), the IJV manager would be expected to exhibit some level of 
commitment to the goals and objectives of the parent company, since the parents created the IJV.

\section{Fairness in Organization and Organizational Commitment}

Justice theories have been used to gain insights into behaviour in organizations since fairness is believed to be an important factor in organizational effectiveness (Fortin and Fellenz, 2008; Greenberg, 1990). Two common sources of organizational fairness (justice) are procedural fairness and distributive fairness. Procedural fairness reflects a person's judgments about the fairness of the process of making outcome allocations decisions whereas distributive fairness refers to the perceived fairness of the amounts of outcomes employees or manager receive in resources allocation (Greenberg, 1990). According to Beugre (1998) and Yagil (2006), the problem of fairness of resources allocation is a critical issue and affects organizational commitment of managers.

\section{Fairness of Strategic Resources Allocation (FSRA) and Organizational Commitment}

Distributive justice relates with the fairness of resources allocation (Milkovich and Newman, 2005). Perceptions of distributive fairness (fairness of resources allocation) have been discovered to have a direct effect on organizational commitment (Alexander and Ruderman, 1987; Folger and Konovsky, 1989, McFarlin and Sweeney, 1992). This relationship can be explained by equity theory (Adams, 1965). According to the equity theory (Adams, 1965), members within a group will compare their input-output ratio to ratios of other members, or to a specific referent within the group. Members of the group expect their outcomes to be proportional to their contributions, together with the respective ratios to resemble those of their referents. Within the context of an IJV, the allocation of resources assigned to the IJV by its parents of an inequitable amount may be interpreted as a visible sign of a lack of parental support for the IJV. Therefore, it is hypothesized that:

$\mathrm{H} 1$ : There is a positive relationship between perceptions of FSRA and team's commitment to multiple parties of the IJV organization.
H1a: There is a positive relationship between perceptions of FSRA and team's commitment to the IJV itself.

$\mathrm{H} 1 \mathrm{~b}$ : There is a positive relationship between perceptions of FSRA and team's commitment to the foreign parent.

H1c: There is a positive relationship between perceptions of FSRA and team's commitment to the local parent.

Fairness of Strategic Resources Allocation (FSRA) and Team's Commitment to Implementing Strategy (TCIS)

The IJV management team's commitment to implementing the IJV's strategy may also be directly affected by the fairness of strategic resources allocation. According to equity theory (Adam, 1965; Tang and SarsfieldBaldwin, 1996), when individuals perceive that they have been treated unfairly, they will attempt to maintain equity by decreasing the quality, and/or the quantity of their outputs. Such a phenomenon can be transposed from an individual level to the group or organizational level of analysis, especially within the context of an IJV.

Adam (1965) and Walster et al. (1978) suggested that when the IJV's management team perceives that the IJV has accepted an inequitable distribution of resources, the team might react by reducing their level of output. In this case, the level of commitment to implementing the IJV's strategy will be lowered. The following hypotheses are formulated:

$\mathrm{H}$ 2: There is a positive relationship between the perceptions of FSRA and TCIS.

$\mathrm{H} 2 \mathrm{a}$ : There is a positive relationship between FSRA within the IJV itself and TCIS

$\mathrm{H} 2 \mathrm{~b}$ : There is a positive relationship between FSRA from foreign parent and TCIS

$\mathrm{H} 2 \mathrm{c}$ : There is a positive relationship between FSRA from local parent and TCIS

The above hypotheses are also supported by the expectancy theory (Beugre, 1998; Lawler, 1971) which relates individual effort to the probability of achieving organizational outcome. When the IJV manager perceives a lack of resources allocation to implement the strategy, the perceived probability of attaining successful performance by these managers is likely to be poor. This is because beliefs about unfair- 
ness in resource allocation will decrease the IJVs' managers' commitment to implementing the IJV strategy.

\section{Team's Commitment to Multiple Parties and TCIS}

The concept of commitment suggests that high organizational commitment will lead to greater efforts in order to achieve organizational goals. Therefore, it can be expected that the IJV team's commitment in achieving organizational goals through implementing IJV strategy will be influenced by management team's commitment to both the IJV and its parents. Therefore, we put forth the following hypotheses:

H3: There is a positive relationship between team's commitments to multiple parties in IJV organization and TCIS.

$\mathrm{H} 3 \mathrm{a}$ : There is a positive relationship between IJVCOM and TCIS

$\mathrm{H} 3 \mathrm{~b}$ : There is a positive relationship between FPCOM and TCIS

$\mathrm{H} 3 \mathrm{c}$ : There is a positive relationship between LPCOM and LPCOM

The Mediating Effect of Team's Commitment to Multiple Parties

The research model (as depicted in Figure 1) predicts that commitment to multiple parties mediates the relationship between FSRA and TCIS. There are three mediating variables, namely: (1) team's commitment to IJV itself,

(2) team's commitment to foreign parent, and

(3) team's commitment to local parent. The following hypotheses are forwarded.

H4: The relationship between the perception of FSRA within IJV and TCIS is mediated by team commitment to multiple parties in IJV organization

H4a: The relationship between FSRA within IJV and TCIS is mediated by IJVCOM

H4b: The relationship between FSRA from foreign parent and TCIS is mediated by FPCOM

$\mathrm{H} 4 \mathrm{c}$ : The relationship between FSRA from local parent and TCIS is mediated by LPCOM

\section{METHODOLOGY Unit of Analysis and Measurements}

The unit of analysis for this study is the management team of an IJV, since the team will be collectively responsible for the successful implementation of the IJV's strategy. Respondents were selected based on IJVs domiciled in Indonesia and their businesses are within the manufacturing sector. Sources of data used to identify the IJV were gathered from the publications of the Indonesian Coordinating Investment Board (BKPM) (2004) and Business Monitoring International (2001). Of the 2809 IJVs that were initially identified, only 798 companies met the ownership criteria.

Structured questionnaires were used in the survey. Questionnaires were sent, drop and collect to the management of the IJVs. The measures used to assess the independent, mediating, and dependent variables of the study were adopted from previous studies listed in Table 1. All responses were based on a 5-point Likert scale.

\section{Analysis}

Methods to assess the goodness of measures (factor analysis and reliability analysis) were conducted in accordance to Sekaran (2003). In conducting factor analysis, the assumptions that recommended by Hair et al. (2006) were followed. They are: (1) KMO measure sampling adequacy greater than.50, (2) Barlett's test of sphericity is at least significant at.05, (3) antiimage correlation of items greater than.50, (4) communalities of items greater than.50, (5) minimum factor loading of.70 for each items, and (6) minimum eigenvalues of 1 . All the variables were found to be unidimensional. To measure the internal consistency of the items, a reliability analysis was conducted on all factors. The minimum acceptability cut-off point for Cronbach's $\alpha$ was set at.70 in accordance to Hair et al. (2006). Table 2 showed the reliability coefficients (Cronbach's alpha) for the variables were above 0.70 . 


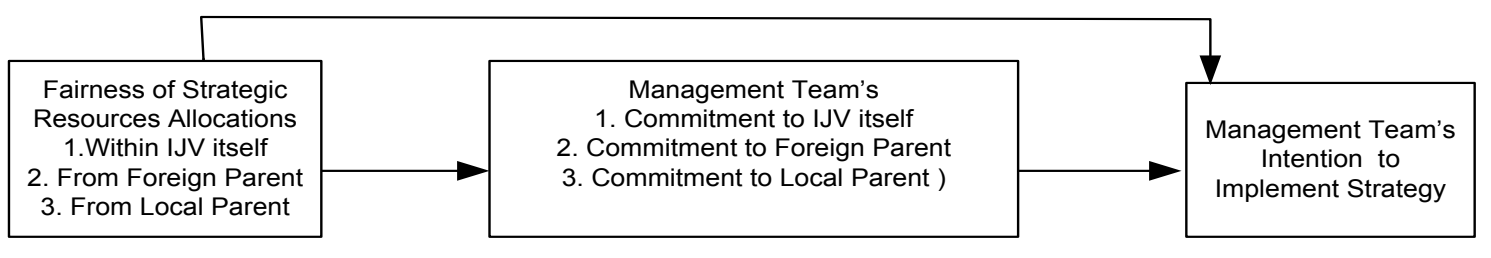

Figure 1: Research Model

Table 1: Summary of Construct, Number of Items, Adapted from, and Measurement

\begin{tabular}{lcl}
\hline \multicolumn{1}{c}{ Construct } & $\begin{array}{c}\text { Number } \\
\text { of items }\end{array}$ & \multicolumn{1}{c}{ Adapted from } \\
\hline Team's Commitment to IJV (IJVCOM) & 15 & OCQ Mowday et al. (1979) \\
Team's Commitment to Foreign Parent (FPCOM) & 15 & OCQ Mowday et al. (1979) \\
Team's Commitment to Local Parent (LPCOM) & 15 & OCQ Mowday et al. (1979) \\
$\begin{array}{l}\text { Fairness of Strategic Resources Allocation } \\
\text { (FSRA) }\end{array}$ & 5 & Beugre (1998); Johnson (2000) \\
$\begin{array}{l}\text { Team's Commitment to Implementing Strategy } \\
\text { (TCIS ) }\end{array}$ & 5 & $\begin{array}{l}\text { Beamish, (1988); Kim and Mauborgne } \\
\text { (1993); Johnson (1998) }\end{array}$ \\
\hline
\end{tabular}

Table 2: Summary of Principal Component and Reliability Analyses of Variables

\begin{tabular}{lccccccc}
\hline \multicolumn{1}{c}{ Variables } & Items & $\begin{array}{c}\text { Factor } \\
\text { Loading }\end{array}$ & $\begin{array}{c}\text { Eigen } \\
\text { value }\end{array}$ & $\begin{array}{c}\text { \% Variance } \\
\text { explained }\end{array}$ & KMO & $\begin{array}{c}\text { Sig. } \\
\text { level }\end{array}$ & $\begin{array}{c}\text { Cronbach's } \\
\text { alpha }\end{array}$ \\
\hline IJVCOM & $15(6)^{*}$ & $.71-.84$ & 5.55 & 62 & .92 & .01 & .90 \\
FPCOM & $15(4)$ & $.71-.90$ & 7.34 & 67 & .94 & .01 & 95 \\
LPCOM & $15(8)$ & $.71-.86$ & 4.49 & 64 & .89 & .01 & .81 \\
FSRA within IJV itself & $6(2)$ & $.79-.89$ & 2.78 & 69 & .78 & .01 & .84 \\
FSRA from Foreign Parent & $5(1)$ & $.74-.88$ & 2.83 & 71 & .81 & .01 & .86 \\
FSRA from Local Parent & $5(1)$ & $.75-.85$ & 2.69 & 67 & .79 & .01 & .84 \\
TCIS & 5 & $.87-.92$ & 3.67 & 68 & .89 & .01 & .95 \\
\hline
\end{tabular}

*Figures in parentheses represent numbers of items deleted

\section{RESULTS}

Of the 798 questionnaires distributed, only 113 were found to be useable for statistical analysis representing a response rate of 14 percent. Profile of the participating IJVs is shown in Table 3. From Table 3 below, it can be seen that the responding IJVs were well-represented because these IJVs were involved in a variety of businesses like chemical, rubber, and plastic $(21.24 \%)$, textile and leathers $(16.81 \%)$, food and beverage (14.16\%), wood, fabricated and metal $(14.16 \%)$, rattan and furniture $(13.27 \%)$, non-metal and mineral product $(9.73 \%)$, iron and steel $(6.19 \%)$, and paper, printing and publishing (4.42\%). Regarding length of operation and ownership, most of length of operation of respondent company had operated between 5 up to 15 years, and the most of ownership $(59.3 \%)$ of the IJVs had their foreign partner as the majority shareholder. In terms of foreign partner's country of origin, the IJVs sampled were from Europe (24.78\%), Japan (20.35\%), Korea (13.27\%), ASEAN (12.39\%), North America (9.73\%), China, Hong Kong, and Taiwan (8.85\%), Australia (7.96\%), and others $(2.62 \%)$.

Table 4 represents the means, standard deviations, and inter-correlations of the variables investigated. As can be observed from Table 4, the coefficients of correlations had ranging (.31 to.81) across all variables. All of the correlations were significant. The mean value for FSRA from FP was $3.94(\mathrm{SD}=.41)$, FSRA from LP was 3.75 (SD =.33), FSRA within IJV was 3.88 ( $\mathrm{SD}=.37)$, commitment to IJV was 4.02 ( $\mathrm{SD}=.35)$, commitment to foreign parent was $3.89(\mathrm{SD}=.41)$, and commitment to local parent was $3.73(\mathrm{SD}=.39)$. Similarly, the mean value for team's commitment to implementing strategy $3.95(\mathrm{SD}=.43)$. 
Table 3: The Profile of Participating IJVs

\begin{tabular}{llcc}
\hline \multicolumn{1}{c}{ Description } & \multicolumn{1}{c}{ Categories } & Frequency & \% \\
\hline & Food, Beverage, and Tobacco & 16 & 14.16 \\
& Textile and Leather & 19 & 16.81 \\
& Wood, Rattan and Furniture & 15 & 13.27 \\
& Paper, Printing and Publishing & 5 & 4.42 \\
Type of Business & Chemical, Rubber and Plastic & 24 & 21.24 \\
& Non-metallic and Mineral Product & 11 & 9.73 \\
& Iron and Steel & 7 & 6.19 \\
& Fabricated Metal & 16 & 14.16 \\
\hline \multirow{5}{*}{ Length of Operation } & Less than 5 years & 8 & 7.08 \\
& $5-15$ years & 70 & 61.95 \\
& More than 15 years & 35 & 30.97 \\
\hline \multirow{5}{*}{ Number of Employees } & Less than 500 & 63 & 55.75 \\
& 500-999 & 22 & 19.47 \\
& 1000- 1499 & 10 & 8.85 \\
& More than 1500 & 28 & 15.93 \\
\hline \multirow{5}{*}{ Share of Ownership } & Equal Ownership & 24 & 21.24 \\
& Foreign Partner Majority & 67 & 59.29 \\
& Local Partner Majority & 22 & 19.47 \\
\hline \multirow{5}{*}{ Foreign Partner's Country of } & North America & 11 & 9.73 \\
Origin & Europe & 28 & 24.78 \\
& Australia & 9 & 7.96 \\
& Japan & 23 & 20.35 \\
& Korea & 15 & 13.27 \\
& China, Hong Kong and Taiwan & 10 & 8.85 \\
& ASEAN & 14 & 12.39 \\
& Others & 3 & 2.62 \\
\hline
\end{tabular}

Table 4: Means, Standard Deviations, and Inter-correlations of Variables

\begin{tabular}{lrrrrrrr}
\hline \multicolumn{1}{c}{ Variables } & \multicolumn{1}{c}{$(1)$} & \multicolumn{1}{c}{$(2)$} & \multicolumn{1}{c}{ (3) } & \multicolumn{1}{c}{ (4) } & \multicolumn{1}{c}{ (5) } & \multicolumn{1}{c}{$(6)$} & \multicolumn{1}{c}{ (7) } \\
\hline FSRA from Foreign Parent (1) & & & & & & & \\
FSRA from Local Parent (2) & $.62^{* *}$ & & & & & & \\
FSRA within IJV itself (3) & $.81^{* *}$ & $.61^{* *}$ & & & & & \\
IJVCOM (4) & $.66^{* *}$ & $.58^{* *}$ & $.61^{* *}$ & & & & \\
FPCOM (5) & $.81^{* *}$ & $.62^{* *}$ & $.71^{* *}$ & $.80^{* *}$ & & & \\
LPCOM (6) & $.32^{*}$ & $.70^{* *}$ & $.31^{*}$ & $.41^{* *}$ & $.37^{*}$ & & \\
TCIS (7) & $.69^{* *}$ & $.63^{* *}$ & $.68^{* *}$ & $.78^{* *}$ & $.81^{* *}$ & $.47 * *$ & \\
MEAN & 3.94 & 3.75 & 3.88 & 4.02 & 3.89 & 3.73 & 3.95 \\
STD DEV & .41 & .33 & .37 & .35 & .41 & .39 & .43 \\
\hline ** Correlation is significant at the 0.01 level: *at the 0.05 level (2-tailed). & & & &
\end{tabular}

** Correlation is significant at the 0.01 level: *at the 0.05 level (2-tailed).

\section{Regression Analysis Predicting Teams' Commitment to Multiple Parties}

The results of regression analysis in Table 5 showed that FSRA within IJV itself had a significant and positive effect $(\beta=.66, p<0.01)$ on IJVCOM. FSRA from foreign parent had a significant $(\beta=.75, p<0.01)$ effect on FPCOM. FSRA from local parent was positively and significantly related $(\beta=.73, p<0.01)$ to LPCOM. Additionally, FSRA within the IJV itself, FSRA from foreign parent, and FSRA from local parent had significant effects on TCIS. The R- square value was .53 indicating that 53 percent of the variance in TCIS can be explained by the independent variables. The F-value of 41.64 was found to be significant $(\mathrm{p}<0.01)$. These results provided support for $\mathrm{H} 1$ and $\mathrm{H} 2$. Furthermore, the results of regression analysis showed that team's commitment to multiple parties had a significant effect on TCIS. The Rsquare value was $.66, \mathrm{p}<.01$ indicating that 66 percent of the variance of TCIS can be explained by variables of commitment to multiple parties. This result provided support for H3. 
Table 5: Summary of Regression Analyses Predicting Teams' Commitment to Multiple Parties and team's commitment to implementing strategy (TCIS)

\begin{tabular}{|c|c|c|c|c|c|}
\hline \multirow{2}{*}{ Predictors } & \multicolumn{3}{|c|}{ Commitment to Multiple Parties } & \multirow{2}{*}{ TCIS } & \multirow{2}{*}{ TCIS } \\
\hline & IJVCOM & FPCOM & LPCOM & & \\
\hline FSRA within IJV itself & $.66^{*}$ & & & .32 & \\
\hline FSRA from Foreign Parent & & $.75^{* *}$ & & .28 & \\
\hline FSRA from Local Parent & & & $.73 *$ & .24 & \\
\hline IJVCOM & & & & & $.33 * *$ \\
\hline FPCOM & & & & & $.49 * *$ \\
\hline LPCOM & & & & & $.15^{*}$ \\
\hline $\mathrm{R}$-square & .44 & .56 & .54 & .53 & .66 \\
\hline square Adjusted & .43 & .56 & .54 & .51 & .65 \\
\hline F-value & $86.56^{* *}$ & $144 * *$ & $132.63 * *$ & $41.64 * *$ & $96.19^{* *}$ \\
\hline
\end{tabular}

Significant level: ${ }^{* *} \mathrm{p}<.01$ and ${ }^{*} \mathrm{p}<.05$

Table 6: Summary of the Mediation Test of Commitment to Multiple Parties on the Relationship between FSRA and TCIS

\begin{tabular}{|c|c|c|c|c|c|c|}
\hline \multirow[b]{2}{*}{ Predictors } & \multicolumn{6}{|c|}{ Dependent and Mediating Variable } \\
\hline & TCIS w/o & TCIS with & TCIS w/o & TCIS with & TCIS w/o & TCIS with \\
\hline FSRA within IJV & $67^{* *}$ & $22 * *$ & & & & \\
\hline FSRA from FP & & & $.66^{* *}$ & $.12 *$ & & \\
\hline FSRA from LP & & & & & $.55^{* *}$ & $.34 * *$ \\
\hline IJVCOM & & $.66^{* *}$ & & & & \\
\hline FPCOM & & & & $.72^{* *}$ & & \\
\hline LPCOM & & & & & & $.29 *$ \\
\hline R-square & .44 & .69 & .43 & .66 & .30 & .34 \\
\hline R- square change & & $.25^{* *}$ & & $.23 * *$ & & $.04 *$ \\
\hline F-value & $90.32 * *$ & $92.41 * *$ & $88.98 * *$ & $77.08^{* *}$ & 49.22 & $6.47 *$ \\
\hline
\end{tabular}

Significant level: $* * \mathrm{p}<.01$ and $* \mathrm{p}<.05$

\section{DISCUSSION}

Fairness of Strategic Resources Allocation and Team's Commitment to Multiple Parties Our study's objective was to examine the relationship between perceptions of FSRA within IJV, from foreign and local parents, and team's commitment to multiple parties. The result of hypothesis testing for the first hypothesis indicates that there is a significant association between perceptions FSRA and commitment to multiple parties in IJV. The result reflects that perceptions of fairness of strategic resource allocation in terms of the amount and form of resource allocation they receive might influence IJVs management team commitment to the IJV itself, foreign parent, and local parent. Team's perceptions of a fair allocation of resources are likely to be influenced by how they assess their outcomes and their input contributions as explained in equity theory (Adam, 1965).

Perceptions of FSRA are related to cognition decisions which stimulate exhibition of team's attitude (i.e. commitment). A positive attitude towards teams' outcomes is likely to occur when there is a belief that the resources allocation received is equitable and proportional when compared to a referent other (Martin, 1981). In other words, team members are more likely to feel satisfied with their outcomes when they believe that the content of resources they perceived as fair is higher than the content of resources they perceive as unfair (Greenberg, 1990). Hence, managers who believed that the resources allocated to them are fair will be more inclined to increase their commitment to their organization. Additionally, beliefs about fair treatment by top management will encourage perceptions of organizational support and diligence (Eisenberg et al., 1990), which in turn, will increase team commitment. In the case of an IJV organization, perception of FSRA can be viewed from the content of resources received by the top management team. Differences in group preferences for the amount of resources allocation could explain the effect of fairness of strategic resources allo- 
cation (distributive fairness) on their attitude and behavior. The relative deprivation theory argued that groups assess their outcomes (i.e. resources allocated) against other outcomes, using some standard comparison criteria. If the groups think that the resources are being fairly allocated, they will feel satisfied, which in turn, will stimulate greater willingness to extend effort on behalf of the employing organization (Tyler and Blader, 2003). This will lead to greater organizational commitment.

Fairness of Strategic Resources Allocation and Team's Commitment to Implementing Strategy

Our second hypotheses relate to relationship between perceptions of fairness of strategic resources allocation within IJV, from foreign and local parents and teams' intention to implementing strategy. Regression results indicate that when teams in the IJV perceive a higher level of justice in terms of content of resources allocation, they are more likely to have a higher commitment to implementing IJVs' strategies. Perceptions of justice might help the teams to improve interpersonal relations among organizational members and develop positive attitudes toward the organization (Beugre, 1998). Sheppard et al. (1992, p.103) notes that "perceptions of justice lead to perceptions of perceived legitimacy, which in turn lead to compliance of the system". Team's agreement to implementing organization strategy can achieve organizational goals. Justice is not an end in organization, but a means to attain more desired goals. Perception of distributive justice might result in teams' behaviour to act in a manner consistent with existing norms toward IJV's strategy. The teams will do so if they perceive that decision-makers behave fairly. In the case of IJV organizations, justice perception of strategic resources allocation (i.e., within IJV, by foreign parent, and local parent) might be able to strengthen commitment of top management team to implement strategy. The commitment of the team is reflected through the way they achieve strategic goals of the IJV organization. These findings are consistent with Leventhal's (1976, 1980) and Beugre (1998) argument who argued that decision-makers will distribute reward equitably in order to maximize on long-term productivity. Natural values of justice might foster effective social cooperation to promote individual well-being. The values can also significantly affect interaction among its members to implementing strategy (Deutsch, 1985). In the case of an IJV organization, decision-makers' decisions (i.e. of the parent company) tend to be based on the expectancy that equitable distribution of resources will stimulate a high level of motivation to execute IJV's strategy. Perceived equitable distribution of resources makes team membership more committed to support the accomplishment of the IJVs' strategic goals.

Consistent with the previous research (Adam, 1965; Walster et al., 1978), perception of distributive justice will foster commitment to implementing strategy. If top management teams perceive they have accepted an inequitable distribution of resources, they will react in several ways such as by reducing their level outputs or lowering positive attitudes (i.e. commitment). As noted by Mowday et al. (1979), commitment involves at least three aspects: (1) a belief and acceptance organizational goals and values, (2) a willingness to exert effort towards organizational goal accomplishment, and (3) a strong desire to maintain organizational membership. These three behavioural aspects will be enhanced when team members of the IJVs top management perceive they have been treated fairly. The team's desire to put the strategy into action might develop as a result of the need to establish a long-term relationship with the parent organization. Therefore, perceived distributive justice of top management team within the IJV will lead to higher level of implementation of the IJV's strategy. This study finds that the relationship between distributive justice of strategic resources allocation and teams' commitment to implementing strategy is insignificant. It should be reminded that, in general, strategic resources allocation of IJV is mostly dominated by parent organization in which majority of top management teams are nominated from parent organization (Kiliing, 1983; Yan, 2000; Yagil, 2006; Yan and Luo, 2001; Lukman, et al., 2007).

\section{Team's Commitment to Multiple Parties and Team's Commitment to Implementing Strategy}

The result of hypothesis testing for the third hypothesis indicates demonstrated that there is 
a positive and significant relationship between the IJV management team's commitment to IJV and its team's commitment to implementing the IJV's strategy. The result implies that when there is a high level of commitment among team members to the IJV, managers within the management team will be more likely to increase their intention to implement the IJV's strategy. This is consistent with Guth and MacMillan (1986) who argued that the level of commitment to implement the IJV's strategy exhibited by IJVs' managers is affected by their perception of organizational support provided by the parent company. In this regard, the IJV managers play a key role in executing the venture's strategy, whereby they can obstruct, delay, or reduce the quality of strategic implementation if they perceive that implementing the strategy is in some way against their selfinterest. The self-interest model implies that in groups, people try to maximize their personal gain when interacting with others (Lind and Tyler 1988; Tyler and Blader, 2003).

Our result showed that there is a positive and significant relationship between management team's commitment to foreign parent and its team's commitment to implementing strategy. This finding is supported by past researchers (Gregersen, 1993; Gregersen and Black, 1992; Johnson, 1999; Johnson et al., 2002) who noted that people hold varying levels of commitment to different organizations within and across the organizational boundaries. Johnson et al. (2002) suggested that "balanced commitment by an IJV management team is likely to result in effective strategy implementation in a way that will satisfy the needs and expectations of the IJV and its parent". This line of argument is consistent with the social identity theory which relates to the process by which individuals come to identify with and form bonds to various groups and organizations (Ashforth and Mael, 1989; Kogut and Zander, 1996). Organizational identification conducted by group might lead to a higher loyalty and commitment to organization (Mowday et al., 1979). This study also confirms that the role of commitment as an antecedent to team joint- effort and collaboration in implementing strategic decisions. Therefore, it is expected that steadiness and stability of commitment by IJV's management team is likely to affect the strategic implementation effectiveness (strategic performance achievement), which in turn, will fulfill the needs and expectations of its parents and the IJV itself.

\section{Mediating Effect of Team's Commitment to Multiple Parties on the Relationship between FSRA and TCIS}

Hypothesis 4 focused on the mediating relationship between perceptions of FSRA within IJV and TCIS (H4a), FSRA from foreign parent and TCIS (H4b), and FSRA from local parent and TCIS (H4c). Our results provided support for a partial mediation. This finding implies that FSRA has both direct and indirect effects on TCIS. In other words, a higher level of perception of FSRA will lead to a higher level team commitment to multiple parties, which in turn, will increase their commitment to implementing strategic decisions in the IJV. In addition, FSRA was found to have a direct effect on TCIS. This result suggests that when the managerial teams' perception of FSRA is high, their TCIS in the IJV will also be high. This finding is consistent with prior findings (Beugre, 1998; Folger and Konovsky, 1989: McFarlin and Sweeney, 1992) who discovered that distributive fairness positively affect organizational commitment.

\section{LIMITATIONS AND SUGGESTIONS FOR FUTURE RESEARCH}

Three main limitations should be highlighted. First, cross-sectional data were utilized. A1though this approach is adequate in gathering data, such design limits the possibility of making causal inferences concerning the various hypothesized relationships. A longitudinal approach is strongly recommended in order to test for causal effects. Second, organization commitment in the present study was conceptualized as a unidimensional contruct, measured by the OCQ (Mowday et al., 1979). Prior wellknown research by Allen and Meyer (1990) has illustrated organizational commitment to consist of three dimensions. Hence, future researchers may want to make use of this measure instead of the OCQ. Third, certain demographic variables were not controlled in this investigation. Given the possibility of confounding effects of these variables, statistically controlling them would be a better option. 


\section{REFERENCES}

Adams, JS. 1965. Inequity in Social Exchange. In L.Berkowitz. (Ed.) Advances in Experimental Psychology, Vol. 2, (pp. 267-299). New York: Academic Press.

Alexander, SJ. and M. Ruderman. 1987. The Role of Procedural and Distributive Justice in Organizational Behaviour, Social Justice Research. 1 (3). 1771198.

Allen, NJ. and JP. Meyer. 1990. The Measurement and Antecedents of Affective, Continuance and Normative Commitment to the Organization. J. Occupational Psychology. 63 (1). 1-18.

Ashforth, BE. and F. Mael. 1989. Social Identity Theory and the Organization. Academy of Management Review. 14 (1). 20-39.

Beamish, PW. 1988. Multinational Joint Ventures in Developing Countries. London: Routledge.

Beugre, CD. 1998. Managing Fairness in Organizations. London. Quorum Books

Blau, PM. 1964. Exchange and Power in Social Life. New York. Wiley \& Sons

Bloomer, J. and GO. Schroder. 2003. Antecedent and Consequences of Affective Commitment. Australian Marketing Journal. 11(3). 33-43.

Buchel, B., C. Prange, G. Prost and RC. Clemens. 1998. International Joint Venture Management: Learning to Cooperate and Cooperating to Learn. Singapore. John Wiley.

Business Monitor International. 2001. Foreign Company in Indonesia Yearbook 2001. London: Commercial Agency Services.

Cohen, A. 2006. Th Relationship between Multiple Commitments and Organizational Citizenship Behaviour in Arab and Jewish Culture. Journal of Vocational Behavior. 35 (2). 15-27

Deutsch, M. 1985. Distributive Justice: A Social Psychological Perspective. New Heaven: Yale University Press
Folger, R. and MA. Konovsky. 1989. Effects of Procedural and Distributive Justice on Reactions to Pay Raise Decisions, Academy of Management Journal. 32 (1). $115-130$.

Fortin, M. and MR. Fellenz. 2008. Hypocrisies of Fairness: Towards a More Reflexive Ethical Base in Organizational, Journal of Business Ethics. 78. 415-433.

Greenberg, J. 1990. Organizational Justice: Yesterday, Today and Tomorrow. Journal of Management. 16 (2). 399-432.

Gregersen, HB and JS. Black. 1992. Antecedent to Commitment to a Parent Company and a Foreign Operation. Academy of Management Journal. 35(1). 65 -90 .

Guth. WD. and IC. Macmillan. 1986. Strategy Implementation versus Middle Management Self-Interest. Strategic Management Journal. 7 (5). p. 313 - 327.

Hamel, G. 1991. Competition for Competency and Inter-Partner Learning within International Strategic Alliances. Strategic Management Journal. 12 (2). 83103.

Hair, JR., Black, WC. Babin, BJ. Anderson, JF. and RL. Tatham. 2006. Multivariate Data Analysis. $6^{\text {th }}$ Eds. New Jersey. Prentice-Hall Inc.

Harrigan, KR. 1986. Managing for Joint Venture Success. Lexington. Lexington Books.

Indonesian Coordinating Investment Board. 2004. Domestic and Foreign Investment Report in Indonesia 2004. Jakarta. BKPM.

Johnson, JP. 1999. Multiple Commitments and Conflicting Loyalties in International Joint Venture. International Journal Organization Analysis. 7 (1). 54-71.

Johnson, JP. 2000. Strategic Decision Making Procedural Justice and Team Commitment in International Joint Ventures: A Path Model Assessment of Relationship. Academy of Management Meeting. Toronto Canada. 
Johnson, JP., MA., Korsgaard and HJ. Sapienza, 2002. Perceived Fairness, Decision Control, and Commitment in IJV Management Teams. Strategic Management. Journal, 23, 1141-1160.

Kim, WC. and RA. Mauborgne. 1991. Implementing Global Strategies: The role of Procedural Justice. Strategic Management Journal. 12 (2). 125-143.

Kogut, B. 1988. Joint Ventures: Theoretical and Empirical Perspectives. Strategic Management Journal. 9. 319-323.

Kogut, B. and U. Zander. 1996. What Do Firm Do: Coordination, Identity, and Learning, Organization Science, 7, 502-518.

Kuvaas, B. 2006. Work Performance, Affective Commitment, and Work Motivation; the Roles of Pay Administration and pay level. Journal of Organizational Behaviour. 27. 365-385.

Lawler, EE. 1971. Pay and Organization Effectiveness: A psychological view. New York. McGraw-Hill Book Coy.

Leventhal, GS. 1980. What Should Be Done with the Equity Theory? In K. J. Gergen. M. S. Greenberg. \& R. H. Willis (Eds.). Social Exchange Advance in Theory and Research. 27-55. New York. Plenum.

Lind, EA. 1995. Social Conflict and Social Justice: Some Lessons from the Social Psychology of Justice. Leiden. The Netherlands. Leiden University Press.

Lind, AE. and TR. Tyler. 1988. The Social Psychology of Procedural Justice. New York: Plenum

Lukman, S., AM. Nasurdin and M. Osman. 2007. Organizational Justice, Decision Control and Commitment to Multiple Parties in Indonesia International Joint Ventures, ICBMR, $2^{\text {nd }}$, Jakarta, 15-17 August, 2007.

Martin, J. 1981. 'Relative Deprivation: A Theory of Distributive Justice for An Era Of Shrinking Resources. In L. L. Cumming \& B.M. Staw (Eds), Research in Organizational Behaviour .3. 53-108), Greenwich, CT: JAI Press.
Mathieu, JE. and DM. Zajac. 1990. A review and meta-analysis of the antecedents, correlates, and consequences of organizational commitment. Psychological Bulletin. 108 (2). 171-194.

McFarlin, DB. and PD. Sweeney. 1992. Distributive and Procedural justice as Predictors of Satisfaction with Personal and Organizational Outcomes, Academic Management Journal. 35 (8). 626-637.

Meyer, JP. and NJ. Allen. 1997. Commitment in Workplace: Theory, Research and Application, Thousand Oaks. California. Sage Publication.

Milkovicch, GT. and JM. Newman. 2005. Compensation Management. $8^{\text {th }}$ Ed. New York. McGraw-Hill

Mowday, RT., RM. Steers and LW. Porter. 1979. The Measurement of Organizational Commitment. Journal of Vocational Behaviour. 14 (2). 224-247.

Mowday, RT., LW. Porter and RM. Steers, 1982. Employee-Organization Linkage: the Psychology of Commitment, Absenteeism, and Turnover, Organization and Occupational Psychology. New York. Academic Press.

Porter, LW., RM. Steers, RT. Mowday and PV. Boulian. 1974. Organizational Commitment. Job Satisfaction. and Turnover among Psychiatric Technicians. Journal of Applied Psychology. 59. 603-609

Reichers, AE. 1985. A Review and Reconceptualization of Organizational Commitment. Academy Of Management Review. 10 (3). 465-476.

Sekaran, U. 2003. Research Methods for Business. Ed. $4^{\text {rd }}$. New York. John Wiley \& Sons.

Sheppard, BH., RJ. Lewicki and JW. Minton. 1992. Organizational Justice: The Search for Fairness in the Workplace. New York. Lexington Books.

Tang, TL. and LJ. Sarsfield-Baldwin. 1996. Distributive and Procedural Justice as Related to Satisfaction and Commit- 
ment. SAM Advance Management Journal. 61 (3). Summer. 25-31

Tiessen, JH. and JD. Linton. 2000. The JV Dilemma: Cooperating and Competing in Joint Ventures. Canadian Journal of Administrative Sciences. 17 (3). 203-216.

Tyler, TR. and SL. Blader. 2003. The Group Engagement Model: Procedural Justice, Social Identity, and Cooperative Behaviour. Personality and Social Psychology Review. 7 (5). 349-361.
Walster, EGW., GW. Walster and E. Berscheid. 1978. Equity: Theory and Research. Boston. Allyn \& Bacon.

Yagil, D. 2006. Perceptions of Justice within Leader-Employee Dyads, International Journal of Organization Theory and Behavior. 9 (3). 291-305.

Yan, Y. 2000. International Joint Venture in China: Ownership, Control and Performance. London. Palgrave MacMillan.

Yan, A. and Y. Luo. 2001. International Joint Venture: Theory and Practice. New York. M.E. Sharpe Inc. 